\title{
Faktor yang Memengaruhi Kualitas Hidup Pasien dengan Penyakit Jantung Koroner
}

\author{
Aan Nuraeni, Ristina Mirwanti, Anastasia Anna, Ayu Prawesti, Etika Emaliyawati \\ Fakultas Keperawatan Universitas Padjadjaran \\ Email : aan.nuraeni@unpad.ac.id
}

\begin{abstract}
Abstrak
Prevalensi Penyakit Jantung Koroner (PJK) terus mengalami peningkatan setiap tahunnya dan menjadi masalah kesehatan utama di masyarakat saat ini. PJK berdampak terhadap berbagai aspek kehidupan penderitanya baik fisik, psikososial maupun spiritual yang berpengaruh terhadap kualitas hidup pasien. Isu kualitas hidup dan faktor-faktor yang berhubungan didalamnya belum tergambar jelas di Indonesia. Tujuan dari penelitian ini adalah mengidentifikasi faktor yang memengaruhi kualitas hidup pada pasien PJK yang sedang menjalani rawat jalan. Faktor-faktor yang diteliti dalam penelitian ini meliputi jenis kelamin, tingkat penghasilan, revaskularisasi jantung, rehabilitasi jantung, kecemasan, depresi dan kesejahteraan spiritual. Kecemasan diukur dengan Zung Self-rating Anxiety Scale, depresi diukur dengan Beck Depression Inventory II, kesejahteraan spiritual diukur dengan kuesioner Spirituality Index of Well-Being dan kualitas hidup diukur menggunakan Seattle Angina Questionnaire. Penelitian ini menggunakan rancangan kuantitatif deskriptif dan analitik multivariate dengan regresi logistic. Diteliti pada 100 responden yang diambil secara random dalam kurun waktu 1 bulan di Poli Jantung. Hasil penelitian menunjukkan faktor yang memengaruhi kualitas hidup pada pasien PJK adalah cemas (p) 0,002; Odd Ratio (OR) 4,736 (95\% confidence interval (CI), 1,749 - 12,827); depresi (p) 0,003; OR 5,450 ( 95\% CI, 1,794 - 16,562); dan revaskularisasi (p) 0,033; OR 3,232 (95\% CI, 1,096 - 9,528). Depresi menjadi faktor yang paling berpengaruh terhadap kualitas hidup pasien PJK. Faktor yang memengaruhi kualitas hidup pada pasien PJK meliputi depresi, cemas dan revaskularisasi. Dari ketiga variabel tersebut depresi merupakan variabel yang paling signifikan berpengaruh, sehingga manajemen untuk mencegah depresi perlu mendapatkan perhatian lebih baik lagi dalam discharge planning ataupun rehabilitasi jantung.
\end{abstract}

Kata kunci: Cemas, depresi, faktor yang memengaruhi, kualitas hidup, spiritual.

\section{Factors Influenced the Quality of Life among Patients Diagnosed with Coronary Heart Disease}

\begin{abstract}
Coronary Heart Disease (CHD) has affected multidimensional aspects of human live nowadays. Yet, quality of life and factors associated with quality of life among people who live with heart disease has not been explored in Indonesia. This study aimed to identify factors influenced the quality of life among people with CHD received outpatient services. Those factors are gender, income, revascularization, cardiac rehabilitation, anxiety, depression and spiritual wellbeing. Zung Self-rating Anxiety Scale was used to measure anxiety where depression level measured using Beck Depression Inventory II. Spirituality index was used to measure spiritual well-being. The quality of life level was measured using the Seattle Angina Questionnaire. This study used quantitative descriptive with multivariate analysis using logistic regression. 100 respondents were randomly selected from the Cardiac Outpatient Unit. Findings indicated factors influenced the quality of life of CHD patients using a significance of $p$-value $<0.005$ were: anxiety $(p=0,002, O R=4,736,95 \% C I, 1,749-12,827)$; depression $(p=0,003 ; O R=5,450,95 \% \mathrm{CI}, 1,794-16,562)$; and revascularizations $(p=0,033 ; \mathrm{OR}=3,232,95 \% \mathrm{CI}, 1,096-9,528)$. Depression was considered as the most significant factor; therefore, managing depression is a priority in the discharge planning or cardiac rehabilitation programme.
\end{abstract}

Keywords: Anxiety, depression, quality of life, spiritual, well-being. 
Aan Nuraeni : Faktor yang Memengaruhi Kualitas Hidup Pasien Jantung Koroner

\section{Pendahuluan}

Penyakit Jantung Koroner (PJK) berdampak terhadap berbagai aspek kehidupan penderitanya. Secara fisik penderita akan merasakan sesak, mudah lelah, mengalami gangguan seksual, serta nyeri dada (Rosidawati, Ibrahim, \& Nuraeni, 2015), selain itu masalah psikososial seperti cemas dan depresi juga sering dialami oleh pasien (Lane, Carroll, \& Lip, 2003; Gustad, Laugsand, Janszky, Dalen, \& Bjerkeset, 2014) ditambah distres spiritual yang dapat terjadi pada pasien-pasien dengan penyakit terminal seperti kanker (Mako, Galek, \& Poppito, 2006), mungkin juga dialami oleh pasien dengan PJK, karena penyakit ini merupakan penyakit akut dan mengancam kehidupan namun membutuhkan perawatan dan penyesuaian gaya hidup yang terusmenerus dan masif sepanjang hidup pasien.

Pencegahan agar tidak terulangnya kembali serangan jantung, pasien dengan PJK perlu melakukan perubahan gaya hidup yang cukup masif. Seperti perubahan dalam pola diet, kebiasaan merokok, pembatasan aktivitas, serta pengendalian stres dan kecemasan. Kondisi ini justru dapat memicu timbulnya distres baru, ditambah lagi perubahan dalam kondisi fisik dan perubahan peran yang terjadi akibat sakit yang berkepanjangan. Beberapa penelitian mengungkapkan bahwa stress, depresi, rendahnya dukungan sosial dan spiritual dapat meningkatkan perburukan kondisi penyakit pada pasien dengan PJK (Aldana et al., 2006; Fukuoka, Lindgren, Rankin, Cooper, \& Carroll, 2007; Davidson et al., 2013). Dan beberapa penelitian lainnya mengungkapkan masih tingginya angka cemas dan depresi pada pasien PJK di Indonesia (Krisnayanti, ; Widiyanti, 2013) sehingga komplikasi dan perburukan pun kemungkinan jumlahnya cukup tinggi.

Perubahan kondisi fisik, psikososial dan spiritual pada pasien PJK berpengaruh terhadap kualitas hidup pasien. Beberapa penelitian menunjukkan hal tersebut diantaranya Christian, Cheema, Smith, dan Mosca (2007) mereka mengungkapkan bahwa terdapat efek negatif yang besar dari penyakit jantung terhadap kualitas hidup penderitanya. Selain itu Failde dan Soto (2006) menyatakan bahwa terjadi penurunan yang signifikan pada dimensi fungsi fisik, kesehatan secara umum, dan vitalitas pada 3 bulan pasca serangan jantung.

Penelitian sebelumnya menyatakan bahwa terdapat hubungan yang erat antara status sosiodemografi dan psikososial pasien PJK dengan kualitas hidup. Terjadi peningkatan kualitas hidup pada pasien yang masih tetap bekerja, menikah, aktif secara fisik dan menjalani rehabilitasi dan tidak depresi pada populasi pasien PJK di Amerika (Christian et al., 2007). Pada penelitian yang dilakukan di Spanyol oleh Failde dan Soto (2006) didapatkan hasil bahwa tidak ada perbedaan kualitas hidup yang signifikan pada pasien yang menjalani monitoring maupun yang drop out. Setelah 3 bulan, terjadi penurunan signifikan pada aspek fisik dan kesehatan secara umum, namun pasien yang menjalani revaskularisasi jantung memiliki kondisi fisik 6,4 poin lebih baik dibanding yang tidak menjalani revaskularisasi. Aspek fisik lebih buruk dirasakan pada pasien dengan usia yang lebih muda dan memiliki lebih dari satu faktor resiko. Penelitian lain yang dilakukan di Singapura menunjukkan hasil bahwa tingkat pendidikan dan depresi secara signifikan dapat memprediksi kondisi fisik pasien sedangkan umur, kecemasan dan depresi dapat memprediksi kesehatan mental pasien dengan penyakit jantung (Muhammad et al., 2014).

Penelitian tentang kualitas hidup pada pasien dengan penyakit PJK di Indonesia sudah banyak dilakukan namun penelitian yang secara khusus menganalisis tentang faktor yang memengaruhi kualitas hidup pada pasien dengan PJK belum banyak dilakukan. Padahal peningkatan kualitas hidup pasien PJK merupakan tujuan dari penatalaksanaan kesehatan pada pasien ini, sehingga studi tentang kualitas hidup serta faktor-faktor yang memengaruhinya penting untuk dilakukan. Dari penelitian ini diharapkan faktor yang memengaruhi kualitas hidup yang ditemukan dari penelitian ini dapat dijadikan bahan pertimbangan dalam intervensi untuk 
Aan Nuraeni : Faktor yang Memengaruhi Kualitas Hidup Pasien Jantung Koroner

meningkatkan kualitas hidup pasien dengan PJK di Indonesia.

\section{Metode Penelitian}

Rancangan penelitian menggunakan metode kuantitatif deskriptif dan analitik multivariat. Peneliti menguji data yang dikumpulkan pada satu kesempatan dengan subjek yang sama (cross sectional). Populasi pada penelitian ini adalah pasien dengan PJK yang menjalani rawat jalan di Ruang Poli Jantung RSUP Dr. Hasan Sadikin Bandung dan sudah menjalani rawat jalan minimal 1 bulan. Sampel pada penelitian ini diambil dengan teknik simple random sampling. Ukuran sampel untuk multiple regresi menurut Sugiyono (2010) adalah minimal 10 responden untuk setiap variabel yang diukur. Dalam penelitian ini terdapat 6 variabel bebas dan satu variabel terikat, total terdapat 7 variabel jumlah sehingga responden minimal adalah 70 , dalam penelitian ini didapatkan responden sebanyak 100 orang.

Kualitas hidup diukur menggunakan instrumen Seattle Angina Questionaire. Kuesioner ini khusus mengukur kualitas hidup pada pasien PJK, didalamnya terdapat 19 pertanyaan meliputi 5 buah dimensi klinis yaitu 1) keterbatasan fisik; 2) stabilitas angina; 3) frekuensi angina; 4) Kepuasan terhadap pengobatan; dan 5) Persepsi terhadap penyakit. Nilai reliabilitas Seattle Angina Questionnaire yaitu 0,83 untuk dimensi keterbatasan fisik, 0,24 untuk dimensi stabilitas angina, 0,76 untuk dimensi frekuensi angina, 0,81 untuk dimensi kepuasan terhadap pengobatan, 0,78 untuk dimensi persepsi terhadap penyakit (Spertus, et al., 1995), kualitas hidup dari subvariabel tersebut selanjutnya akan dihitung secara keseluruhan kemudian dikategorikan ke dalam kategori tinggi dan rendah.

Kecemasan diukur dengan menggunakan Zung self-Rating Anxiety Scale (SAS) yang dirancang oleh William W. K. Zung pada tahun 1971 dikembangkan berdasarkan gejala kecemasan dalam Diagnostic and Statistical Manual of Mental Disorders (DSM-II). Kuesioner ini berisi 20 item pernyataan yang terdiri dari 15 item untuk pernyataan tentang peningkatan kecemasan dan 5 item untuk pernyataan tentang penurunan kecemasan. Zung Self-rating Anxiety Scale memiliki nilai validitas 0,66 yang meningkat menjadi 0,74 pada pasien yang didiagnosis gangguan kecemasan Zung Self-rating Anxiety Scale mempunyai nilai alpha cronbach 0,85 (McDowell, 1989).

Alat ukur depresi dalam penelitian ini menggunakan instrumen Beck Depression Inventory II (BDI-II) versi bahasa Indonesia yang sudah dilakukan uji construct validity oleh Ginting, Naring, Veld, Srisayekti, \& Becker (2013) dengan nilai validasi $r=0,55$, $\mathrm{p}<0,01$ dan reliabilitas yang diukur dengan alpha cronbach sebesar 0,90. Selanjutnya Spirituality Index of Well-Being digunakan untuk mengukur tingkat kesejahteraan spiritual. Instrumen ini dikembangkan oleh Daaleman \& Vande Creek (2000) Kuesioner Spirituality Index of Well-Being dan memiliki nilai reliabilitas 0,70 . Sebelum digunakan instrumen-instrumen ini dilakukan back translation dan dilakukan uji validitas dan reliabialitas.

Uji yang digunakan untuk melihat hubungan antar variabel dilakukan analisis data bivariate menggunakan uji Rank Spearman. Dan untuk menentukan faktor yang memengaruhi yang paling dominan selanjutnya dilakukan analisis data multivariate dengan teknik multiple regresi logistic menggunakan metode backward stepwise (wald) mengingat variabel terikat berupa data kategorik dikotomi. Hasil analisa data disajikan dalam bentuk tabel, dan uraian narasi.

\section{Hasil Penelitian}

Dari seratus orang responden sebagian besar berusia lebih dari 45 tahun (91\%) dan berjenis kelamin laki-laki (77\%) serta memiliki penghasilan antara $1-3$ juta per bulan $(51 \%)$. Selain itu sebanyak 53\% responden tidak menjalani revaskularisasi jantung dan hanya $39 \%$ yang menjalani rehabilitasi jantung namun sebagian besar responden saat dikaji tidak memiliki penyakit penyerta $(64 \%)$ serta tidak memiliki kebiasaan merokok (93\%).

Variabel independen yang memiliki 
Aan Nuraeni : Faktor yang Memengaruhi Kualitas Hidup Pasien Jantung Koroner

hubungan signifikan dengan variabel dependen (kualitas hidup) adalah revaskularisasi, rehabilitasi jantung, cemas, depresi dan kesejahteraan spiritual, lebih lanjut keseluruhan korelasi tersebut memiliki tingkat kesalahan $1 \%(\mathrm{p}<0,001)$. Cemas dan depresi memiliki koefisien korelasi (r) negatif, hal ini berarti semakin tinggi kecemasan dan depresi maka kualitas hidup akan semakin rendah. Sebaliknya revaskularisasi, rehabilitasi jantung, dan kesejahteraan spiritual memiliki nilai $r$ positif hal ini berarti pasien yang menjalani revaskularisasi, rehabilitasi jantung dan memiliki kesejahteraan spiritual yang tinggi akan memiliki kualitas hidup yang tinggi.
Hal ini digambarkan lebih lengkap dalam tabel 1 .

Dalam pemodelan terdapat dua variabel independen yang tidak dapat diikutkan dalam analisis multivariat yaitu variabel penghasilan dan penyakit penyerta. Hasil analisis multivariat ditampilkan pada tabel 2. Tabel 2 tersebut tidak terlihat lagi variabel jenis kelamin dan kesejahteraan spiritual. Kedua variabel tersebut dikeluarkan dari pemodelan karena memiliki nilai signifikansi (p) > 0,05 serta nilai $\mathrm{p}$ yang lebih besar dibandingkan dengan variabel lainnya, dan setelah dikeluarkan tidak merubah nilai Exp $\mathrm{B}(\mathrm{OR})>10 \%$ pada variabel yang lain. Dari tabel 2 tersebut juga dapat dilihat bahwa

Tabel 1 Hubungan antara Jenis Kelamin, Penghasilan, Penyakit Penyerta, Revaskularisasi Jantung, Rehabilitasi Medik, Cemas, Depresi , SIWB dan Kualitas Hidup.

\begin{tabular}{|c|c|c|c|c|c|c|c|c|c|c|}
\hline & & $\begin{array}{c}\text { Jenis } \\
\text { Kelamin }\end{array}$ & $\begin{array}{c}\text { Peng- } \\
\text { hasilan }\end{array}$ & $\begin{array}{l}\text { Penyakit } \\
\text { Penyerta }\end{array}$ & $\begin{array}{c}\text { Revaskul- } \\
\text { arisasi }\end{array}$ & $\begin{array}{c}\text { Rehab } \\
\text { Jantung }\end{array}$ & Cemas & Depresi & SIWB & $\begin{array}{c}\text { Kualitas } \\
\text { Hidup }\end{array}$ \\
\hline $\begin{array}{l}\text { Jenis } \\
\text { Kelamin }\end{array}$ & (r) & 1 & $-0,184$ & $-0,097$ & $-0,086$ & $-0,01$ & $0,438 * *$ & 0,216 & $-0,142$ & $-0,128$ \\
\hline $\begin{array}{l}\text { Peng- } \\
\text { hasilan }\end{array}$ & (r) & $-0,184$ & 1 & 0,074 & 0,167 & $-0,173$ & $-0,026$ & $-0,120$ & $0,267^{*}$ & 0,016 \\
\hline $\begin{array}{l}\text { Penyakit } \\
\text { Penyerta }\end{array}$ & (r) & $-0,097$ & 0,074 & 1 & $-0,023$ & $-0,058$ & $-0,043$ & $0,280 * *$ & $-0,156$ & $-0,098$ \\
\hline $\begin{array}{l}\text { Revasku- } \\
\text { larisasi }\end{array}$ & (r) & $-0,086$ & 0,167 & $-0,023$ & 1 & $0,438 * *$ & $-0,134$ & $-0,132$ & $-0,118$ & $0,335 * *$ \\
\hline $\begin{array}{l}\text { Rehab } \\
\text { Jantung }\end{array}$ & (r) & 0,001 & 0,173 & $-0,058$ & $0,438 * *$ & 1 & $-0,132$ & $-0,059$ & 0,141 & $0,317 * *$ \\
\hline Cemas & (r) & $0,438 * *$ & $-0,026$ & $-0,043$ & $-0,134$ & $-0,132$ & 1 & $0,371 * *$ & $-0,197$ & $-0,414 * *$ \\
\hline Depresi & (r) & $0,216^{*}$ & $-0,120$ & $0,280 * *$ & $-0,132$ & $-0,059$ & $0,371 * *$ & 1 & $-0,571$ & $-0,481 * *$ \\
\hline SIWB & (r) & $-0,142$ & $0,267 * *$ & $-0,156$ & 0,118 & 0,141 & $-0,197$ & $-0,571 * *$ & 1 & $0,336 * *$ \\
\hline $\begin{array}{l}\text { Kualitas } \\
\text { Hidup }\end{array}$ & (r) & $-0,128$ & 0,016 & $-0,098$ & $0,335^{* *}$ & $0,317 * *$ & $-0,414 * *$ & $-0,418 * *$ & $0,336^{* *}$ & 1 \\
\hline
\end{tabular}

Keterangan :

$*_{\mathrm{p}}<0,05 ; * * \mathrm{p}<0,01$

Tabel 2 Analisis Multivariate dengan Regresi Logistik

\begin{tabular}{lcccccccc}
\hline & B & S.E. & Wald & df & Sig. & Exp (B) & \multicolumn{2}{c}{ 95\% C.I for EXP (B) } \\
\cline { 6 - 9 } & & & & & & & Lower & Upper \\
\hline Cemas & 1,555 & 0,508 & 9,361 & 1 & 0,002 & 4,736 & 1,749 & 12,827 \\
$\begin{array}{l}\text { Depresi } \\
\text { Rehabilitasi }\end{array}$ & 1,696 & 0,567 & 8,942 & 1 & 0,003 & 5,450 & 1,794 & 16,562 \\
jantung & 1,032 & 0,558 & 3,426 & 1 & 0,064 & 2,807 & 0,941 & 8,376 \\
$\begin{array}{l}\text { R e v a s - } \\
\text { kularisasi }\end{array}$ & 1,173 & 0,552 & 4,524 & 1 & 0,033 & 3,232 & 1,096 & 9,528 \\
Constant & $-3,157$ & 0,665 & 22,525 & 1 & 0,000 & 0,043 & & \\
\hline
\end{tabular}


Aan Nuraeni : Faktor yang Memengaruhi Kualitas Hidup Pasien Jantung Koroner

variabel cemas, depresi dan revaskularisasi merupakan faktor yang memengaruhi dari kualitas hidup karena memiliki nilai signifikansi $<0,05$, sedangkan variabel rehabilitasi jantung merupakan faktor confounding dari variabel revaskularisasi karena nilai OR berubah $>10 \%$ setelah rehabilitasi jantung dikeluarkan dari model, artinya pasien yang menjalani revaskularisasi jantung memiliki kualitas hidup 3,23 kali lebih tinggi dibandingkan dengan pasien yang tidak menjalani revaskularisasi jantung setelah variabel cemas, depresi dan rehabilitasi medis dikontrol. Pasien yang tidak mengalami kecemasan, kualitas hidupnya lebih tinggi 4,7 kali dibanding pasien yang cemas setelah faktor revaskularisasi dan depresi dikontrol. Dan pasien dengan depresi minimal kualitas hidupnya lebih tinggi sebanyak 5,4 kali dibanding pasien yang mengalami depresi setelah faktor cemas dan revaskularisasi dikontrol. Variabel yang memiliki pengaruh terbesar terhadap kualitas hidup dapat terlihat dari nilai exp (B) yang paling tinggi dalam hal ini depresi menjadi faktor terbesar yang memengaruhi kualitas hidup responden.

\section{Pembahasan}

Berdasarkan hasil analisis multivariate, dapat diketahui bahwa yang menjadi faktor yang memengaruhi kualitas hidup pada pasien PJK dalam penelitian ini adalah cemas, depresi, dan revaskularisasi jantung dengan depresi menjadi faktor yang paling berpengaruh terhadap kualitas hidup pasien PJK dibanding kedua faktor yang lain. Lebih jauh hasil penelitian menjelaskan bahwa pasien PJK yang tidak mengalami kecemasan kualitas hidupnya 4,7 kali lebih baik dibanding pasien cemas, sedangkan pasien yang tidak mengalami depresi memiliki kualitas hidup 5,4 kali lebih baik dibanding dengan pasien depresi dan pasien yang menjalani revaskularisasi memiliki kualitas hidup 3,23 kali lebih baik dibanding pasien yang tidak menjalani revaskularisasi.

Pasien dengan PJK secara fisik mengalami berbagai perubahan yang dapat berpengaruh terhadap aspek lainnya seperti aspek psikologis dan spiritual. Secara fisik pasien dapat mengalami angina, sesak, mudah lelah serta gangguan seksual (Rosidawati et al., 2015) dan secara psikologis pasien dengan PJK sering mengalami cemas dan depresi (Aldana et al., 2006; Fukuoka, Lindgren, Rankin, Cooper, \& Carroll, 2007; Davidson et al., 2013), lebih lanjut Sarafino dan Smith (2014) mengungkapkan bahwa masalah psikososial yang dialami oleh pasien dengan penyakit kronis adalah cemas, depresi, kemarahaan, dan keputusasaan. Cemas dan depresi yang dialami oleh pasien PJK menurut Amin, Jones, Nugent, Rumsfeld, dan Spertus (2006) dapat terjadi karena diagnosis dokter tentang penyakit serius, status kesehatan yang memburuk, intervensi pengobatan, dan kekambuhan gejala yang berulang.

Stres, cemas maupun depresi secara langsung dapat memengaruhi jantung. Berawal dari stimulasi sistem saraf simpatis kemudian akan meningkatkan heart rate (HR), kecepatan konduksi melalui AV node, dan kekuatan kontraksi atrial dan ventrikel jantung serta vasokonstriksi pembuluh darah yang akan mengaktifkan sistem renin angiotensin. Kondisi tersebut akan meningkatkan kebutuhan supply oksigen di jantung, sedangkan pasien dengan PJK memiliki gangguan dalam aliran darah koroner dengan kata lain kebutuhan oksigen yang meningkat tersebut sulit untuk terpenuhi (Lewis, Heitkemper, \& Dirksen, 2010; Monahan, Sands, Neighbors, Marek, \& Green, 2007). Efek yang muncul akibat dari gangguan pemenuhan oksigenasi dapat berupa nyeri dada, sesak, intoleransi aktivitas dan meningkatkan pula stress ataupun kecemasan yang sudah dialami sebelumnya. Lebih lanjut disebutkan bahwa depresi dapat meningkatkan reaksi inflamasi dimana reaksi ini merupakan bagian intrinsik dari timbulnya atherosclerosis dan berhubungan dengan pelepasan sitokin ( $C$-reactive protein dan IL-1 dan IL-6) (Frasure-smith, Théroux, \& Irwin, 2004), oleh Ridker, Hennekens, RoitmanJohnson, Stampfer, dan Allen (1998) disebut sebagai penanda inflamasi masih menurut Ridker, et al (1998) penanda inflamasi ini merupakan faktor yang memengaruhi dari insidensi PJK dan menurut Lindmark, Diderholm, Wallentin, \& Siegbahn (2001) dapat memperburuk prognosis pasien dengan PJK.

Efek buruk akibat cemas maupun depresi 
Aan Nuraeni : Faktor yang Memengaruhi Kualitas Hidup Pasien Jantung Koroner

seperti yang diuraikan diatas antara lain sesak, nyeri dada, dan intoleransi aktivitas dapat meningkatkan keterbatasan fisik, frekuensi angina (nyeri dada), dan mengganggu stabilitas angina. Kondisi tersebut dapat memperburuk penyakit dan gejala yang dialami sehingga memungkinkan timbulnya persepsi yang buruk terhadap penyakit, dan rendahnya kepuasaan terhadap pengobatan. Kelima parameter tersebut merupakan bagian dari kualitas hidup yang diukur dalam penelitian ini, sehingga sangat mungkin ditemukan munculnya korelasi negatif antara variabel cemas maupun depresi dengan kualitas hidup pasien PJK seperti yang terlihat dalam hasil penelitian ini. Sehingga kedua variabel ini menjadi faktor yang memengaruhi dalam menentukan kualitas hidup pasien tersebut.

Cemas dan depresi memiliki perbedaan dalam tingkat keparahan maupun durasi kejadiannya. Kecemasan menurut Videbeck (2014) adalah perasaan tidak nyaman atau takut dan mungkin memiliki firasat akan ditimpa malapetaka padahal ia tidak mengerti mengapa emosi tersebut terjadi. Kecemasan dalam batas-batas tertentu dianggap sebagai hal positif sebagai peringatan terhadap adanya ancaman, sehingga individu dapat mempersiapkan proses penyesuaian diri yang lebih efektif (Sadock, Kaplan, \& Sadock, 2007). Sedangkan depresi disebut juga sebagai mood disorder menurut Videbeck (2014) merupakan perubahan dalam emosi yang dimanifestasikan dengan depresi, mania atau keduanya. Hal ini memengaruhi kehidupan seseorang, dengan kesedihan yang sangat mendalam dalam jangka waktu yang panjang, agitasi ataupun kegembiraan, menyertai keraguan diri, rasa bersalah, dan kemarahan dan mengubah kehidupan terutama berkaitan dengan harga diri, pekerjaan dan hubungan sosial. Berdasarkan uraian diatas dapat dilihat bahwa depresi memiliki pengaruh negatif yang lebih besar terhadap seseorang dibandingkan dengan kecemasan, sehingga efeknya pun terhadap kualitas hidup pasien dengan PJK akan jauh lebih berat, apalagi depresi terjadi dalam jangka waktu yang lama. Kesedihan yang berkepanjangan akan memengaruhi kemampuan aktivitas fisik dan sosial seseorang sehingga dampak penurunan kualitas hidup pada penderita
PJK pun menjadi lebih tinggi dibandingkan dengan pasien yang hanya mengalami cemas saja.

Depresi merupakan faktor yang memengaruhi yang paling signifikan terhadap kualitas hidup. Berdasarkan beberapa penelitian yang sudah dilakukan hal ini dapat terjadi salah satunya berkaitan dengan serotonin. Di dalam neuron keberadaan serotonin yang berikatan dengan reseptor serotonin dapat mengaktivasi sinyal kimiawi yang dipercaya dapat memengaruhi fungsi psikologis seseorang (pengaturan mood, hasrat seksual, tidur, nafsu makan) (Belmaker \& Agam, 2008). Serotonin secara eksklusif disimpan dalam sirkulasi platelet di perifer (Markovitz \& Matthews, 1991 dalam Sanner, 2011). PJK sangat erat kaitannya dengan injuri vaskuler, dan platelet akan melakukan agregasi dalam merespon hal ini termasuk didalamnya serotonin yang tersimpan dalam platelet (platelet serotonin). Platelet serotonin ini menstimulasi agregasi platelet lebih lanjut pada tempat injury tersebut dan berkontribusi terhadap perkembangan thrombosis (Libby \& Théroux, 2005). Thrombosis yang terbentuk dapat menyebabkan sumbatan baru pada arteri koroner dan menimbulkan serangan baru.

Para ilmuwan pada awalnya menduga bahwa penurunan serotonin berhubungan dengan kejadian depresi namun pendapat ini kemudian terbantahkan setelah ditemukannya Serotonin Reuptake Inhibiting Drugs (SRID). Namun demikian masih belum jelas apakah depresi berhubungan dengan penurunan atau peningkatan kadar serotonin, para peneliti menyatakan bahwa SSRI mampu mengembalikan kadar serotonin kembali normal pada pasien depresi. Menurut Dayan dan Huys (2008) depresi berkaitan dengan peningkatan aktivitas dari sistem serotonin (Dayan \& Huys, 2008). Temuan ini memperkuat dugaan terhadap hubungan antara depresi dengan PJK. Menurut hasil penelitian Sanner (2011) bahwa terjadi peningkatan platelet agregasi sebagai respon dari peningkatan platelet serotonin pada pasien depresi bahkan pada sebagian pasien depresi ditemukan adanya peningkatan platelet agregasi yang cukup tinggi walaupun peningkatan platelet serotoninnya minimal, jika dibandingkan dengan pasien yang tidak 
Aan Nuraeni : Faktor yang Memengaruhi Kualitas Hidup Pasien Jantung Koroner

mengalami depresi.

Faktor lain yang memengaruhi kualitas hidup pasien jantung koroner adalah revaskularisasi. Revaskularisasi adalah suatu tindakan membuka sumbatan yang terjadi pada pasien dengan PJK. Tindakannya dapat berupa terapi trombolitik, percutaneous coronary intervension (PCI) dan coronary artery by pass graft (CABG). Revaskularisasi merupakan satusatunya faktor yang memengaruhi positif yang mampu meningkatkan kualitas hidup pasien PJK dalam penelitian ini. Dengan terbukanya kembali aliran darah koroner hal ini dapat meningkatkan perfusi pada otot jantung sehingga dapat meningkatkan kembali cardiac output (CO) yang terganggu akibat gangguan kontraktilitas miokard. Peningkatan $\mathrm{CO}$ dapat meningkatkan aliran darah yang membawa oksigen dan nutrisi ke seluruh tubuh sehingga metabolisme dapat berjalan dengan baik lebih lanjut hal ini akan meningkatkan kemampuan fisik pasien, menurunkan frekuensi angina, meningkatkan persepsi yang baik terhadap penyakit, serta meningatkatkan kepuasaan terhadap pengobatan. Peningkatan dari parameter tersebut akan berpengaruh terhadap peningkatan skor kualitas hidup pasien. Namun demikian sumbatan dapat kembali terjadi pada pasien yang sudah menjalani terapi revaskularisasi jantung terutama pada pasien yang tidak menjalankan pola hidup sehat termasuk didalamnya ketidakmampuan dalam mencegah timbulnya cemas dan depresi.

Penelitian ini menemukan bahwa rehabilitasi jantung merupakan faktor confounding dari revaskularisasi jantung artinya revaskularisasi jantung baru akan meningkatkan kualitas hidup sebanyak 3,23 kali jika variabel rehabilitasi jantung, cemas dan depresi dikontrol. Rehabilitasi jantung dalam penelitian ini tidak termasuk kedalam faktor yang memengaruhi kualitas hidup. Beberapa penelitian sejalan dengan hasil ini antara lain penelitian yang dilakukan di Hongkong yang menyebutkan bahwa tidak ada perbedaan yang signifikan dalam persepsi kualitas hidup pada pasien yang menjalani rehabilitasi jantung ataupun tidak (Chan, Chau, \& Chang, 2005), lebih lanjut penelitian ini menyatakan bahwa partisipasi dalam program rehabilitasi jantung tidak memiliki efek signifikan dalam persepsi kualitas hidup. Penelitian lain dengan hasil serupa dilakukan oleh Tavella dan Beltrame (2012) dalam penelitian tersebut dikatakan bahwa rehabilitasi jantung tidak memengaruhi kualitas hidup baik yang diukur secara generik maupun spesifik. Padahal dalam penelitian sebelumnya disebutkan bahwa rehabilitasi jantung ini berhubungan dengan penurunan gejala angina, peningkatan kebugaran fisik, mengontrol tekanan darah, dan aritmia serta meningkatkan aliran darah koroner dan meningkatkan kesehatan psikologis pasien PJK (Connolly, 2009). Masih banyak faktor yang belum diketahui yang memengaruhi perbedaan hasil penelitian ini, hal ini merupakan tantangan bagi praktisi kesehatan untuk terus memperbaiki dan meningkatkan program rehabilitasi jantung yang sudah ada agar semakin baik dan mampu meningkatkan kualitas hidup pada pasien dengan PJK.

\section{Simpulan}

Berdasarkan hasil penelitian yang sudah dilakukan dapat disimpulkan bahwa faktor yang memengaruhi kualitas hidup pada pasien PJK meliputi depresi, cemas dan revaskularisasi. Depresi dan cemas merupakan faktor yang memengaruhi negatif sedangkan revaskularisasi jantung merupakan faktor yang memengaruhi positif untuk kualitas hidup. Dari ketiga variabel tersebut depresi merupakan variabel yang paling signifikan memengaruhi kualitas hidup pada pasien PJK. Hal ini memungkinkan karena depresi berhubungan dengan pelepasan katekolamin, dan pelepasan faktor-faktor penanda inflamasi serta disfungsi serotonin. Faktor-faktor tersebut berperan dalam meningkatkan kebutuhan oksigen pada jantung serta dapat memperburuk kejadian thrombosis pada pasien dengan PJK. Kondisi tersebut baik secara langsung maupun tidak langsung berpengaruh terhadap kemampuan fisik pasien, frekuensi dan stabilitas angina, persepsi terhadap penyakit, serta kepuasaan terhadap pengobatan, kelima hal ini merupakan dimensi dari kualitas hidup yang diukur dalam penelitian ini.

Fokus peningkatan kualitas hidup pada 
Aan Nuraeni : Faktor yang Memengaruhi Kualitas Hidup Pasien Jantung Koroner

pasien PJK masih menitikberatkan pada aspek fisik, diet dan gaya hidup saja walaupun saat ini sudah banyak dilakukan penelitian yang mempelajari hubungan dan dampak aspek psikologis maupun spiritual terhadap kualitas hidup. Berdasarkan penelitian ini stress, cemas maupun pencegahan depresi perlu mendapatkan perhatian yang lebih baik lagi melalui berbagai program manajemen stress, cemas dan depresi terutama di dalam program rehabilitasi jantung. Selain itu perlu dilakukan penelitian lebih lanjut menyangkut faktor-faktor yang memengaruhi depresi pada pasien PJK untuk melihat lebih jauh lagi penyebab depresi yang terjadi sehingga kedepan intervensi yang diberikan dapat lebih tepat mengatasi penyebab.

\section{Daftar Pustaka}

Aldana, S. G., Whitmer, W. R., Greenlaw, R., Avins, A. L., Thomas, D., Salberg, A., ... Fellingham, G. W. (2006). Effect of intense lifestyle modification and cardiac rehabilitation on psychosocial cardiovascular disease risk factors and quality of life. Behavior Modification, 30(4), 507-25. http:// doi.org/10.1177/0145445504267797.

Amin, A. ., Jones, A. M. ., Nugent, K., Rumsfeld, J. ., \& Spertus, J. . (2006). The prevalence of unrecognized depression in patients with acute coronary syndrome. American Heart Journal, 152(5), 928-934. Retrieved from http://ovidsp.ovid.com/ ovidweb.cgi? $\mathrm{T}=\mathrm{JS} \& \mathrm{PAGE}=$ reference $\& \mathrm{D}=\mathrm{e}$ $\operatorname{med} 7 \& N E W S=N \& A N=2006527695$.

Belmaker, \& Agam, G. (2008). Major Depressive Disorder. The New England Journal of Medicine, 358, 55 - 68. http://doi. org/10.1056/NEJMra073096

Chan, D. S. K., Chau, J. P. C., \& Chang, A. M. (2005). Acute coronary syndromes: Cardiac rehabilitation programmes and quality of life. Journal of Advanced Nursing, 49, 591-599. http://doi.org/10.1111/j.13652648.2004.03334.x.

Christian, A. H., Cheema,A. F., Smith, S. C., \& Mosca, L. (2007). Predictors of quality of life among women with coronary heart disease. Quality of Life Research: An International Journal of Quality of Life Aspects of Treatment, Care and Rehabilitation, 16(3), 363-73. http://doi.org/10.1007/s11136-0069135-7.

Connolly, S. (2009). Cardiac rehabilitation should be tailored to the patient. In Symposium Cardiovascular medicine (Vol. 253, pp. 22,24-26). Retrieved from http://www.ncbi. nlm.nih.gov/pubmed/19606611.

Daaleman, T. P., \& VandeCreek, L. (2000, November). Placing religion and spirituality in end-of-life care. JAMA: The Journal of the American Medical Association.

Dayan, P., \& Huys, Q. J. M. (2008). Serotonin, Inhibition, and Negative Mood. PLoS Computational Biology, 4(2), e4. http://doi. org/10.1371/journal.pcbi.0040004.

Davidson, K. W., Bigger, J. T., Burg, M. M., Carney, R. M., Chaplin, W. F., Czajkowski, S., ... M, G. (2013). Centralized, Stepped, Patient Preference-Based Treatment for Patients With Post-Acute Coronary Syndrome Depression. JAMA Internal Medicine, 173(11), $997 . \quad \mathrm{http}: / /$ doi. org/10.1001/jamainternmed.2013.915.

Failde, I. I., \& Soto, M. M. (2006). Changes in Health Related Quality of Life 3 months after an acute coronary syndrome. BMC Public Health, 6, 18. http://doi.org/10.1186/14712458-6-18.

Frasure-smith, N., Ph, D., Théroux, P., \& Irwin, M. (2004). The Association Between Major Depression and Levels of Soluble Intercellular Adhesion Molecule 1,. American Journal of Psyc, 161, 271-277.

Fukuoka, Y., Lindgren, T. G., Rankin, S. H., Cooper, B. A., \& Carroll, D. L. (2007). Cluster analysis: a useful technique to identify elderly cardiac patients at risk for poor quality of life. Quality of Life Research, 16(10), 1655-1663. http://doi.org/10.1007/ s11136-007-9272-7.

Ginting, H., Näring, G., van der Veld, W. 
Aan Nuraeni : Faktor yang Memengaruhi Kualitas Hidup Pasien Jantung Koroner

M., Srisayekti, W., \& Becker, E. S. (2013). Validating the Beck Depression InventoryII in Indonesia's general population and coronary heart disease patients. International Journal of Clinical and Health Psychology, 13(3), 235-242. http://doi.org/10.1016/ S1697-2600(13)70028-0.

Gustad, L. ., Laugsand, L. ., Janszky, I., Dalen, H., \& Bjerkeset, O. (2014). Symptoms of anxiety and depression and risk of acute myocardial infarction: the HUNT 2 study. European Heart Journal, 35(21), 1394-403. http://doi.org/10.1093/eurheartj/eht387.

Gustad, L. T., Laugsand, L. E., Janszky, I., Dalen, H., \& Bjerkeset, O. (2014). Symptoms of anxiety and depression and risk of acute myocardial infarction: the HUNT 2 study. European Heart Journal, 35(21), 1394-403. http://doi.org/10.1093/eurheartj/eht387.

Krisnayanti, K. D. (n.d.). Depresi dan cemas Pada PAsien dengan Sinrom Koroner Akut.

Lane, D., Carrol, D., \& Lip, G. Y. H. (2003). Anxiety, Depression, and Prognosis after Myocardial Infarction. Journal of the American College of Cardiology, 42(10), $1808-1810$. http://doi.org/10.1016/j. jacc.2003.08.018.

Lewis, S. M., Heitkemper, M. M., \& Dirksen, S. R. (2010). Medical Surgical Nursing Assesment and Management of Clinical Problems (7th ed.). St. Louis: Mosby.

Libby, P., \& Théroux, P. (2005). Pathophysiology of Coronary Artery Disease. Circulation, 111(25), 3481-3488. http://doi.org/10.1161/ CIRCULATIONAHA.105.537878.

Lindmark, E., Diderholm, E., Wallentin, L., \& Siegbahn, A. (2001). Relationship between interleukin 6 and mortality in patients with unstable coronary artery disease: Effects of an early invasive or noninvasive strategy. Journal of the American Medical Association, 286(17), 2107-2113. Retrieved from http:// www.embase.com/search/results?subaction= viewrecord\&from=export\&id=L34041595 nhttp://sfxhosted.exlibrisgroup.com/sfxtul?si $\mathrm{d}=$ EMBASE\&issn $=00987484 \& \mathrm{id}=$ doi:\&atit le $=$ Relationship + between + interleukin $+6+$ an $\mathrm{d}+$ mortality + in + patients + with + unstable + cor onary+arter.

Mako, C., Galek, K., \& Poppito, S. R. (2006). Spiritual pain among patients with advanced cancer in palliative care. Journal of Palliative Medicine, 9(5), 1106-1113. http:// doi.org/10.1089/jpm.2006.9.1106.

McDowell, I. (1989). Measuring Health - a Guide To Rating Scales and Questionnaires. The Journal of the Canadian Chiropractic Association (Vol. 33). Oxford University Press. http://doi. org/10.1179/108331900786166731.

Monahan, F. D., Sands, J. K., Neighbors, M., Marek, J. ., \& Green, C. J. (2007). Phipps' Medical Surgical Nursing: Health And Illness Persfective (8th ed.). philadelphia: Mosby Elsevier.

Muhammad, I., He, H.-G., Koh, K., Thompson, D. R., Kowitlawakul, Y., \& Wang, W. (2014). Health-related quality of life and its predictors among outpatients with coronary heart disease in Singapore. Applied Nursing Research: ANR, 27(3), 175-80. http://doi.org/10.1016/j.apnr.2013.11.008.

Ridker, P. M., Hennekens, C. H., RoitmanJohnson, B., Stampfer, M. J., \& Allen, J. (1998). Plasma concentration of soluble intercellular adhesion molecule 1 and risks of future myocardial infarction in apparently healthy men. Lancet. http://doi.org/10.1016/ S0140-6736(97)09032-6.

Rosidawati, I., Ibrahim, K., \& Nuraeni, A. (2015). Kualitas Hidup Pasien Pasca Bedah Pintas Arteri Koroner (BPAK) Di RSUP DR Hasan Sadikin Bandung. Universitas Padjadjaran.

Sadock, B. J., Kaplan, H. I., \& Sadock, V. A. (2007). Synopsis of Psychiatry Behavioral Sciences/Clinical Psychiatry (Tenth). Philadelphia: Lippincott Williams \& Wilkins.

Sanner, E. J. (2011). The Role of Serotonin in Depression and Clotting in The Coronary Artery Disease Population. The University 
Aan Nuraeni : Faktor yang Memengaruhi Kualitas Hidup Pasien Jantung Koroner

of Texas Health Science Center at Houston School of Nursing.

Sarafino, E. P., \& Smith, T. W. (2014). Health Psychology: Biopsychosocial Interactions (8th ed.). New Jersey: Wiley.

Spertus, J. A., Winder, J. A., Dewhurst, T. A., Deyo, R. A., Prodzlnski, J., Mcdonell, M., \& Fihn, S. D. (1995). Development and Evaluation I? f the Seattle Angina Questionnaire: A New Functional Status Measure for Coronary Artery Disease, 25(2).

Sugiyono. (2010). Metode Penelitian Kuantitatif Kualitatif \& RND. Bandung : Alfabeta.
Tavella, R., \& Beltrame, J. F. (2012). Cardiac rehabilitation may not provided a quality of life benefit in coronary artery disease patients. BMC Health Services Research, 12(1), 406. http://doi.org/10.1186/1472-6963-12-406.

Videbeck, S. L. (2014). Psychiatric Mental Nursing. (Sixth, Ed.)Psychiatric Mental Health Nursing. Philadelphia: Lippincott Williams \& Wilkins.

Widiyanti, M. (2013). Hubungan Antara Depresi, Cemas dan Sindrom Koroner Akut. Retrieved July 16, 2015, from http://download.portalgaruda.org/article. php? article $=14464 \&$ val $=970$. 